\title{
Toplumsal Değişimin Bir Göstergesi Olarak Gençlerin Evliliğe Yönelik Tutumları
}

\author{
Mehmet Erkol* 1, Meryem Şahin ${ }^{2}$, Şehriban Avcı ${ }^{3}$
}

Özet: Türkiye'de yaşanan sosyo-ekonomik dönüşümden en fazla etkilenen kurumların başında aile gelmektedir. Aile kurmanın ilk aşaması olan evlilik de yaşanan bu süreçten etkilenmektedir. Dünyadaki gelişmelere paralel olarak evlenme yaşının yükselmesi, bekâr kalma, evlilik dışı cinsellik, alternatif birlikteliklerin yaygın hale gelmesi gibi durumlar evliliğe ilişkin tutumların değiştiğini düşündürmektedir. Bununla birlikte sosyal bilimlerde evlilik etrafında yapılan tartışmalarda bu değişim yeterince ilgi görmemektedir. Araştırma, toplumun en dinamik unsuru olan gençlerin evlenme yaşı ve evlilikle ilişkili algılarını anlamaya çalışan nitel bir araşıımadır. Araştırma yaşları 20 ile 27 arasında değişen 28 üniversite öğrenci üzerinde gerçekleştirilmiştir. Nitel araştırma yöntemlerinden fenomenolojik yaklaşımla yürütülen araştırmada yarı yapılandırılmış görüşmeler gerçekleştirilmiş; gençlerin ideal evlilik yaşı algıları, evlilik ve aileye bakışları araştırılmışırı. Buna göre çoğunlukla 25 ve üzeri yaşta evlenmeyi idealleştirdikleri görülmüş̧ür. İdeal evlilik yaşında ön plana çıkan faktörler ekonomik bağımsızlık kazanma, eğitimi tamamlama, özgürlüğün kısıtlanmasını istememe, olgunlaşma, kariyer yapmadır. Gençlerin evliliği erteleme eğiliminde olmalarına rağmen, evlenmeye ilişkin motivasyonlarının olduğu görülmüştür. Araştırma bulgularına göre gençler evliliği hayatın önemli bir parçası olarak görmekle birlikte, içinde bulundukları yaş döneminde evliliğe hazır olmadıklarını düşünmekte, daha ideal bir evlilik için evliliği erteleme eğiliminde olmaktadırlar. Evliliğin ertelenmesinde ekonomik engellerle birlikte, gençlerin anlam dünyalarındaki sosyolojik ve psikolojik bariyerlerin de etkili olduğu görülmüsştür.

Anahtar Kelimeler: Toplumsal Değişim, Evliliğin Ertelenmesi, İdeal Evlilik Yaşı, Evlilik Hazır Bulunuşluğu

\section{Youth Attitudes Towards Marriage as an Indicator of Social Change}

Abstract: A family is the most influenced institution by socio-economic transformations in Turkey. Marriage which is the first stage of establishing a family is also affected by this process. In parallel with the developments in the world, situations such as increasing age of marriage, being single, extramarital sexuality, and alternative partnerships becoming widespread suggest that attitudes towards marriage change. However, this change does not attract enough attention in the discussions around marriage in social sciences. The research is qualitative research that attempts to understand the perceptions of the youth, the most dynamic element of the society, about marriage and marriage ages. It has been carried out on 28 university students whose ages ranged from 20 to 27. In the research carried out with a phenomenological approach, semi-structured interviews have been conducted, and the perceptions of young people about ideal marriage age and their attitudes on marriage and family have been investigated. Accordingly, it has been seen that they mostly idealized marriage at the age of 25 and above. The factors that stand out in the ideal age of marriage are gaining economic independence, completing education, not wanting to restrict freedom, maturing, making a career. Although young people tend to delay marriage, it has been observed that they have motivations for marriage. According to the research findings, although young people see marriage as an important part of life, they think that they are not ready for marriage during their age, and tend to delay marriage for a more ideal marriage. Along with economic obstacles, sociological and psychological barriers in the meaning worlds of young people are also effective in delaying marriage.

Keywords: Social Change, Delaying Marriage, The Ideal Age of Marriage, Marriage Readiness

\footnotetext{
${ }^{1}$ Afyon Kocatepe Üniversitesi, Sosyoloji Bölümü (Kadın ve Aile Araştırmaları Uygulama ve Araştırma Merkezi), Afyonkarahisar, Türkiye, mehmeterkol1@ gmail.com, ORCID ID: 0000-0002-1363-1894

${ }^{2}$ Afyon Kocatepe Üniversitesi, Psikoloji Bölümü(Kadın ve Aile Araştırmaları Uygulama ve Araşıırma Merkezi), Afyonkarahisar, Türkiye, meryemsahin@aku.edu.tr, ORCID ID: 0000-0003-0566-8862

${ }^{3}$ Afyon Kocatepe Üniversitesi, Sosyoloji Bölümü, Afyonkarahisar, Türkiye, sehribanavci7@gmail.com, ORCID ID: 0000-0001-8806-492X

Received: 16 February 2021, Accepted: 03 April 2021, Online: 30 April 2021

${ }^{*}$ Corresponding Author
} 


\section{Giriş}

"Yetişkin bir erkek ile yetişkin bir kadın arasındaki yasal geçerliliği olan, belirli hak ve yükümlülükler getiren bir ilişki" (Marshall, 1999, s. 223) olarak tanımlanan evlilik, sosyal bilimlerde üzerinde en çok araştırma ve tartışma yapılan konuların başında gelmektedir. Aile ve evlilik üzerinde yapılan çalışmaların artarak devam etmesi, onun toplumsal değişimden en fazla etkilenen kurumların başında gelmesinden kaynaklanmaktadır. Sosyal bilimlerde değişim, değerden bağımsız hem olumlu hem de olumsuz anlamlar içeren yansız bir kavramdır. Sosyal bilimlerde yansız bir kavram olduğu genel kabulüne karşın araştırmacının içinde yaşadığı toplum, hayata bakışı, içinde bilgi ürettiği epistemik topluluk, değişime olumlu ya da olumsuz anlam atfetmesine neden olabilmektedir. Araştırmacı, toplumsal yapıda ortaya çıkan gerçekliği anlamak için neyin değişip nelerin süreklilik arz ettiğini tayin etmek durumundadır. Çünkü değişimin toplumda ortaya çıkardığı sorunları anlamak sosyal bilimlerin en önemli amaçlarından birisidir (Sunar, 2018). Toplumsal değişim, tabir yerinde olursa değişimin topluma getirdiği maliyetin sistematik olarak araştırılmasıdır. Söz konusu toplumsal sorunların anlaşılması olunca aile etrafında yapılan tartışmalar bir kat daha önem arz etmektedir.

\subsection{Aile Yapısında Meydana Gelen Değişim}

Sanayi Devrimi sonrası batıda ortaya çıkan toplumlarda aile yapısı bilindiği üzere geniş aileden çekirdek aileye doğru bir gelişim göstermiş, 20. yüzyılın son çeyreğine kadar çekirdek aile, ideal aile tipi olarak görülmüştür. Anne, baba ve evlenmemiş çocuklardan oluşan çekirdek aile artık istikrarlı bir şekilde varlığın sürdürerek batı dışındaki toplumlar için de örnek kabul edilmiş̧, çekirdek aile modeli giderek gelenekselleşmiştir. Zamanla bu aile tipi klasik aile tarzı haline dönüşmüştür. Kendi başına yeterli ekonomik birim olarak görülen aile, bu işlevini giderek yitirmiş aile içi iş bölümü başka kurumlara devredilmiştir (Yıldırım, 2011). Ailede meydana gelen değişim, ailenin kendi başına yeterli ekonomik birim olmasından kaynaklı ile sınırlı bir değişim değildir. O zamana kadar statünün kaynağı olan aile, konumunu toplumdaki yerinden alırken zamanla statünün belirleyicisi olmaktan uzaklaşmıştır. Aile; ekonomik işlevini başka birimlere bıraktığı gibi, üyeleri için güvence kaynağı olma, dinin gereklerinin öğretildiği ve uygulandığı ortam sağlama, boş zamanların değerlendirilmesinde üyelerine yol gösterme gibi işlevlerini de diğer kurumlara bırakmıştır (Aydın, 2019). Oldukça özelleşen yönleriyle aile üremenin, bakımın ve toplumsallaşmanın yeri olarak varlığını sürdürmüştür. 1970'lerden sonra ideal aile modeli olarak kabul edilen bu aile tipinde bozulmalar ortaya çıkmış (Sayın, 2020), doğurganlık ve evlenme konusundaki davranış değişiklikleri daha belirgin hale gelmeye başlamıştır. Doğurganlık ile nüfusun 
kendini yenileme fırsatı ortadan kalkmış gözükmektedir (TÜİK, 2019). Yanı sıra evlenmeler ileri yaşlara ertelenmektedir. İstatistiksel verilere, kurumsal düzeyde yayımlanan raporlara ve dünyada konuya dikkat çeken akademik bir dizi çalışmaya (Başar, 2020; Eurostat, 2018; Jones ve Yeung, 2014; TÜİK, 2020)

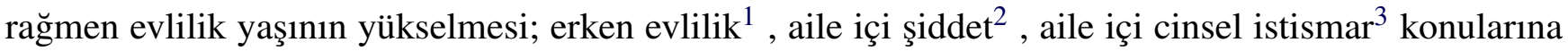
kıyasla hak ettiği ilgiyi görmemiş, toplumsal bir sorun olarak değerlendirilmemiştir. Türkiye'de evlilik yaşının geriye dönük verileri incelendiğinde, 2001 yılında ortalama ilk evlenme yaşı kadınlarda 22.7, erkeklerde 26 iken; 2009 yılında gelindiğinde kadınlarda 23,5'e, erkeklerde 26,8'e çıkmış; bu yükseliş devam ederek 2019 yılında kadınlar için 25 ve erkekler için 27,9 olmuştur (TÜİK, 2020). Amerika Birleşik Devletleri'nde yapılan araştırmaya göre 20. yüzyılın ortalarından bu yana ilk evlilikte ortalama yaş istikrarlı bir şekilde artmaktadır. ABD'de 1950’lerde ortalama evlilik yaşı kadınlar için 20, erkekler için 22 iken; 2018 yılına gelindiğinde kadınlar için 28'e, erkekler için 30'a yaklaşmıştır (Payne, 2017). Yine ABD'de yapılan diğer bir araştırmanın bulguları benzer bir tespit yapmaktadır. Badger (2005) ABD'de 150'si kadın ve 104'ü erkek olmak üzere, lisans ve lisansüstü eğitimine devam eden 254 öğrenci üzerinde yaptığı araştırmada, erkek ve kadınlar ideal evlilik yaşını 25 olarak belirtmiş, evliliği erteleme eğiliminin yükselme trendinde olduğu gözlemlenmiştir.

Evlilik yaşının yükselmesi, sadece batıya özgü bir gelişme değildir. Özellikle gençler üzerinde yapılan araştırmalarda evlilik yaşının yükselmesi, İslam ülkelerinin de gündeminde yer alan toplumsal bir sorundur. İran'da yaşları 19 ile 35 arasında değişen 21 bekâr genç üzerinde yürütülen çalışmada minimum evlenme yaşı 20 olarak belirtilmiştir. Araştırmacılar, minimum yaş olarak 20 belirtilmesine rağmen, İran toplumunda kişilerin 20'lerin sonu ve 30'ların başında evlenme eğiliminde olduğunu ifade etmiştir (Ghalili vd., 2012). Tıpkı İran gibi İslam ülkesi olan Pakistan’da da evliliğin ertelenmesi toplumsal sorun olarak görülmektedir. Al-Idah ve Farhadullah'ın (2017) yaptıkları çalışmada Pakistan'da evliliğin ertelenmesinin popülerleşen bir eğilim olduğu dile getirilmektedir. Benzer şekilde Asya ülkelerinde de evlilik yaşı giderek yükselmektedir (Jones, 2010). Bu ülkelerin temel ahlaki değerlerini belirleyen Konfüçyus öğretisi, gelişimin ancak evlilik yoluyla gerçekleştiği bir toplum inşa etmiştir (Yu-lan, 2019). Son zamanlarda bu anlayışın değişmeye başladığı görülmektedir. En genel şekliyle Asya ülkelerinin evlilik anlayışında evlenme yaşının yükselmesi ve hiç evlenmeyen kişilerin sayısındaki artış olmak üzere belirgin iki değişiklik göze çarpmaktadır. Japonya, Tayvan, Güney Kore ve Hong Kong'un zengin bölgelerinde, ortalama evlilik yaşı kadınlarda 30; erkeklerde ise 33'e yükselmiştir. Son 30 yıl içinde bu rakamın 5 yıl arttığı kaydedilmektedir. 2010 yılında

\footnotetext{
${ }^{1}$ Yüksek Lisans ve doktora seviyesinde 2000-2018 yılları arasında "geç evlilik", "evliliğin ertelenmesi” ile ilgili araştırma bulunmamasına rağmen "erken evlilik”ler üzerinde 29 çalışma tespit edilmiştir. bkz. https://tez.yok.gov.tr/UlusalTezMerkezi/tezSorguSonucYeni.jsp (Erişim Tarihi:10.05.2020).

${ }^{2}$ Yüksek Lisans ve doktora seviyesinde 1997-2020 yılları arasında "aile içi şiddet” üzerinde 468 çalışma tespit edilmiştir. bkz. https://tez.yok.gov.tr/UlusalTezMerkezi/tezSorguSonuc Yeni.jsp (Erişim Tarihi:10.05.2020).

${ }^{3}$ Yüksek Lisans ve doktora seviyesinde 2006-2020 yılları arasında "cinsel istismar" üzerinde 412 çalışma tespit edilmiştir. bkz. https://tez.yok.gov.tr/UlusalTezMerkezi/tezSorguSonucYeni.jsp (Erişim Tarihi:10.05.2020).
} 
Japonya'daki kadınların üçte biri 30 yaşına bekâr olarak girmiş̧tir. Bunların da yarısının hiç evlenmeyeceği tahmin edilmektedir (The Economist, 2011).

\subsection{Toplumsal Norm ve Değerler}

Normlar, toplumsal düzenleme, denetim ve toplumsal düzenle çok yakından ilişkilidir. Sosyolojik bir kavram olarak norm, çoğunlukla bir toplumsal konuma bağlanmış normlar kümesi şeklinde tanımlanan sosyolojik rol kavramıyla yakından bağlantılıdır. Parsonscı kuram, normların, bireylerin yapması gereken şeylerle ilgili inançları yansıttığını ve toplumsallaşma aracılığıyla kişinin güdüleniminin bir parçası haline geldiğini, dolayısıyla insanların, topluma uyum sağlamayı istemeleri nedeniyle kendi toplumlarının normlarıyla tam bir uyum içinde hareket etmeye başladıklarını ileri sürmektedir (Marshall, 1999). Kişilerin normlara uyumsuzluğu söz konusu olduğunda ise akla değerler çatışması gelmektedir. Değerler, kişilerin düşünce tutum ve davranışlarında birer ölçüt olarak toplumsal hayatın onlarsız olamayacağı unsurlardır. Diğger bir deyişle değerler, toplumda neyin uygun olduğu, neyin uygun olmadığını gösteren pusula görevi üstlenirler. Toplumsal değişimin hızlandı̆̆ı dönemlerde geleneksel değerler ile ortaya çıkan yeni değerler arasında çatışma ortaya çıkabilmektedir. Bundan dolayı kimi sosyolog tarafindan toplumsal sorunların temelinde değerlerin farklılaşmasının yattığı ileri sürülmüş̧ür (Groenemeyer, 2007).

Aile, değerlerin öğrenilip içselleştirildiği temel kurumlardandır. En genel anlamda erkek, kadın, çocuk ve yakın akrabalardan oluşan, içinde yoğun etkileşimin gerçekleştiği, kendi içinde üyelerinin sorunlarını çözen, toplumsal normların içselleştirilip toplumsallaşma yoluyla değerlerin öğretildiği aile, geleneksel anlamını yitirmeye başlamıştır. Bireyi çepeçevre kuşatan aile, çocuğun ergenlikten yetişkinliğe kadar hayatının en önemli devresini şekillendirip onu bir kimliğe büründürdüğü gibi yetişkinliğin de ölçülerini belirlemektedir. Aile temelli bir toplumda evlenme ve ebeveyn olma yetişkinliğin en önemli işareti sayılmakta; bunlar değerler hiyerarşisinde ilk sıralarda yer almaktadır (Atak vd., 2016). Günümüzde ise yetişkinliğin işareti olarak kabul edilen evli ve ebeveyn olma geleneksel anlamını kaybetmiş gözükmektedir. Evliliğin ertelenmesi eğilimi gelişim psikolojisinde yeni bir gelişimsel dönemin tanımlanmasına etkide bulunmuştur. Beliren yetişkinlik (emerging adult) olarak tanımlanan bu dönem, gençlerin ergenlikten çıkıp kendilerini yetişkin olarak gördükleri, ancak henüz evlilik kalıplarına girmedikleri ve aile sorumluluklarının alınmadığı kendine özgü uzun bir periyod olarak tanımlanmaktadır. Bu dönemde evlilik, ebeveyn olma, eğitimi tamamlama ve kendine ait bir evde yaşama gibi yetişkinliğe geçiş belirleyicileri olan özellikler ileriye doğru ertelenmiş, 20'li yaşlardaki gelişimsel özellikler değişmiştir (Arnett, 2000). Başkasına karşı sorumlu olma yerine kendi sorumluluğunu almak, bağımsız kararlar verebilmek ve ekonomik olarak 
bağımsız olmak yetişkinlik için yeni değerler olarak belirmiştir. Bunun sonucu olarak, gençler kendilerini 18-19 yaşlarında yetişkin görmelerine karşın, tam olarak yetişkin gibi hissetmeleri yıllar almaktadır (Atak vd., 2016). Bu yaş aralığındaki gençlerin kendilerini arada kalmış hissetmeleri dönemin en belirgin özelliğidir. Gençler, ergen ve yetişkin hissi arasında gidip gelmekte; ergenlik dönemini tamamladıklarını belirtmekle birlikte kendilerini tam bir yetişkin olarak tanımlayamamaktadır. Günümüzde yetişkinliğe atfedilen anlamın değişmesi gençler arasında evliliğin ertelenmesinin sebepleri arasındadır. Buradaki ana sorun, evlilik yaşının sayısal yükselişi değil, bu yaş aralığındaki gençlerin yetişkinlik rollerine girememeleridir. $\mathrm{Bu}$, eş tercihlerinden iş yaşamlarına, çocuk sahibi olmak ya da olmamak arasındaki kararsızlıklarına, tüketim alışkanlarına ve cinsellik ile ilgili tutumlarına kadar hayatlarının önemli bir kısmını etkilemektedir.

Dünyadaki gelişmelere paralel olarak Türkiye'de de gençler arasında bekâr ama birlikte yaşama (KONDA, 2020) giderek hayat tarzı haline gelmektedir. Söz konusu hayat tarzı, bir dizi sorun ortaya çıkarmaktadır. Stein'in (1980; akt. Giddens, 2000) yaşı 25 ile 45 yaş arasında olan 65 bekâr insanla yaptı̆̆ı araştırmanın sonuçları bekâr kalma ve bekârlığı yaşam tarzı olarak benimsemenin sebeplerini ortaya koyması açısından önemlidir. Bu araştırmaya göre katılımcılar, bekâr olmanın kariyer için bir firsat ve yararlı olduğunu, bekâr olmanın çeşitli cinsel deneyimlere imkân tanıdı̆̆ını ve her şeyden daha önemlisi bekârlığın özgürlük ve özerklik olduğunu belirtmişlerdir. Buna göre toplumsal bir değer olarak sorumluluk başkasına dolayımı ile kendine karşı duyulan ilişkisellikten uzaklaşarak yatırımın kendisine yapıldığı bireyin yeni değeri olmaktadır. Bağlantısız ve bağımsız birey olarak gençler, piyasa temelli liberal değerlere kolayca eklemlenebilmektedir. Piyasa temelli liberal sistemin merkezinde ise tüketim bulunmaktadır. Gençlerin medeni durumlarının alışkanlıklarını ne derece etkilediğinin analiz edildiği “Türkiye’de Gençlerin İyi Olma Hali Araştırması”nda sigara, alkol kullanımı, kumar gibi alışkanlıklar, fast-food restoranlarında yemek yemek gibi tüketim temelli bir yaşam tarzının, evli ve bekâr olmaya göre farklılaştığ1 tespit edilmiştir (Erdoğan, 2017).

Aile kurumunun en önemli unsurlarından biri olan çocuk da gençlerin evlilik algılarını belirlemektedir. Genel itibariyle gençlerin çocuk sahibi olmayı eğitim, kariyer yapma, ekonomik şartlar ile birlikte düşündükleri, “bakabileceğin kadar çocuk yapmak”tan, söz konusu sebeplerle “çocuk sahibi olmayı erteleme” arası bir rasyonelleştirme çabası içinde oldukları görülmektedir (Şimal, 2019). Henüz gençlerin genelinde “kendine sorulmadan çocuk dünyaya getirme”nin ahlaki olmadı̆̆ı düşüncesi (Benetar, 2018) belirgin değilse de günümüz gençlerinin bir kısmının evlilik sonrası çocuk sahibi olma fikrine karşı oldukları görülmektedir (KONRAD, 1998). Sosyal medya etkileşimi çok yoğun ve etkin olan gençlerin ekonomik sebepler, kariyer yapma, psikolojik hazır olma ile değerlendirdikleri çocuk (Uğur, 2018), 
dünyada giderek yaygınlaşan üreme karşıtı (anti-natalist) düşünce ile etkileşim içinde yeni bir evlilik anlayışını (çocuksuz evlilik) ortaya çıkarma potansiyeli taşımaktadır.

İstatiksel veriler eşliğinde değerlendirildiğinde evlilik yaşının yükselmesi, tıpkı dünyada olduğu gibi Türkiye'de de ailenin geleceğini bekleyen bir dizi değişimin ve sorunun varlığına işaret etmekte, evlilik dışı birlikte yaşama, evlilik dışı cinsel ilişki, alternatif evlilik modelleri, tüketim alışkanlıklarının dönüşmesi gibi evliliğe ilişkin değerlerde farklılaşma olduğunu düşündürmektedir. Bu araştırma Simmel'in (Akt., Nedelmann, 2001) belirttiği üzere sosyal bilimlerin çözüm üretmekten daha çok sorunu kurmak gibi bir görevi olduğundan hareketle akademik ilgiyi, toplumun geniş kısmını etkileyen bir durum olarak evliliğin ertelenmesine çekmeyi amaçlamaktadır. Buna yönelik olarak saha çalışması gerçekleştirilerek; gençlerin evlenme yaşı ve evliliğe ilişkin tutumlarının araştırılması amaçlanmıştır.

\section{Yöntem}

\subsection{Araştırma Modeli}

$\mathrm{Bu}$ araştırma nitel araştırma desenlerinden fenomenolojik analize (olgu bilim) dayanmaktadır. Fenomenolojik desen insanların günlük hayatta deneyimledikleri fakat derinlemesine bir anlayışa sahip olmadığı olgulara odaklanıp, kişilerin deneyimlere yükledikleri anlam üzerinde çalışmakta (Yıldırım ve Şimsek, 2006), bir olguya ilişkin tecrübeleri tanımlamak, anlatmak ve yorumlamak amacıyla kullanılmaktadır (Kabakçı-Yurdakul, 2016). Araştırmada bu yaklaşıma uygun olarak yarı yapılandırılmış görüşme tekniği kullanılmıştır.

\section{2 Çalışma Grubu}

Araştırma, Afyon Kocatepe Üniversitesi’nde öğrenim gören ve görüşme yapmayı kabul eden 14'ü kadın, 14’ü erkek olmak üzere 28 öğrenci üzerinde gerçekleştirilmiştir. Çalışma grubu seçilirken basit rastlantısal örnekleme yöntemi kullanılmıştır (Aziz, 2014). Evli olmak dışlama kriteri olarak ele alınmış olup, katılımcıların tamamı bekârdır. Çalışma grubunun yaşı 20 ile 27 arasında değişmektedir, yaş ortalaması 22'dir. Katılımcıların 24'ü lisans, 3'ü yüksek lisans ve 1'i doktora eğitimine devam etmektedir. 


\subsection{Veri Toplama Aracı ve Veri Toplama Süreci}

Çalışmada araştırmacılar tarafından oluşturulan yarı yapılandırılmış görüşme formu kullanılmıştır. Görüşme formunun ilk bölümünde katılımcının sosyo-demografik özelliklerine ilişkin sorular, sonrasında ise ideal evlenme yaşı, evlilik kurumuna bakış açılarıyla ilgili sorular sorulmuştur. Görüşmeler 2019 yılı Aralık ayında Afyonkarahisar'da gerçekleştirilmiş ve görüşmeler esnasında ses kaydı alınmıştır. Görüşmeler öğrencilerin kendi talep ettikleri mekanlarda (fakülte kantini, yurt, kampüs, kafe, kütüphane vb.) yüz yüze gerçekleştirilmiş, ortalama 30 dakika sürmüştür.

\subsection{Verilerin Analizi}

Verileri analize hazırlamak için öncelikle görüşmelere dair her ses kaydı birebir yazıya geçirilmiş, sonrasında yazılı dökümler üzerinden içerik analizi ve betimsel analiz yapılmıştır. Analiz sürecinde katılımcılara cinsiyetlerine göre 1-K, 2-E şeklinde kodlar verilmiş, betimsel analiz yapılırken bu kodlar kullanılmıştır. İçerik analizinin gerçekleştirilmesi esnasında veriler araştırmanın problem cümleleri ışığında kodlanmış ve temalar bulunmuştur. İlk etapta yapılan kodlamanın ardından, tüm metinler tekrar 2. tur analize tabi tutulmuş, kodlanan metinler üzerinde tekrarlayan okumalar yapılmıştır. Bu sayede kodlardaki binişiklik ve fazlalıklar ortadan kaldırılmıştır. Araştırmada verilerden yola çıkılarak, tümevarımsal analiz yöntemi kullanılmıştır.

Nitel veri analizinde bilgisayar yazılımları, verilere daha sistematik ve bütüncül bakmayı sağlayarak gözden kaçabilecek verilere daha farklı açılardan bakma imkanı sağlamaktadır (Bazeley ve Jackson, 2015; Kabakçı ve Yurdakul, 2016). Bu araştırmada veri analiz süreci NVivo nitel veri analizi programının 2020 sürümünden faydalanılarak gerçekleştirilmiştir. Kodlamalar programın "Codes” bölümünde gerçekleştirilmiş, kodlamalar sonucu ortaya çıkan kategori ve temalar "Maps" bölümüyle ilişkilendirilerek görsel hale getirilmiştir. Programın “Case Classification” aracı ile cinsiyete dair sınıflandırmalar gerçekleş- tirilmiş, Query aracı kullanılarak "Word Frequency" ve "Matrix Coding” analizi yapılmıştır.

\subsection{Geçerlik ve Güvenirlik}

Nitel araştırmalara geçerlik ve güvenirlik konusunda getirilen eleştirileri azaltmak için, araştırmada bazı önlemler alınmıştır. Bulgular 28 kişilik çalışma grubunun görüşme içeriklerinden oluşan veri setinden elde edilmiştir. Kullanılan veri miktarının inanırlığı sağlamada etkili olduğu düşünülmektedir. Çalışma 
grubunun seçimi, çalışma grubunun özellikleri, veri toplama ve analiz süreçleri yöntem bölümünde açıklanmıştır. Görüşmeler esnasında veri kaybını engellemek amacıyla ses kaydı alınmıştır. Dış güvenirliği sağlamak için ses kayıtları, görüşme dökümleri, kodlama içerikleri dijital olarak muhafaza edilmektedir. Araştırmanın iç güvenirliğini sağlayabilmek için temaları yansıtan örnek ifadeler, doğrudan alıntılarla verilerek betimsel bir yaklaşım sergilenmiştir. Bu sayede bazı veriler doğrudan katılımcıların ifade ettikleri şekilde sunularak, okuyucuların elde edilen bulguları değerlendirmesine imkân sağlanmıştır. Nitel araştırma yürütürken bilgisayar destekli programların kullanılması, elle kodlamaya oranla analiz sürecindeki hata payını azaltmakta, bu sayede araştırma sonuçlarının geçerlik ve güvenirliğini artırmaya yardım etmektedir (Seggie ve Bayyurt, 2015). Bu araştırmada NVivo programından faydalanılması geçerlik ve güvenirliği artıran faktörlerden biridir. Ayrıca araştırma ekibinde nitel araştırma tecrübesi olan araştırmacılar bulunmaktadır.

\section{Bulgular ve Tartışma}

Araştırmanın bulguları katılımcıların evlenme yaşına ilişkin tutumları ve evliliğe ilişkin tutumları olmak üzere iki başlık altında aktarılmıştır. Araştırmaya katılan öğrencilerin evlenme yaşına ilişkin tutumları; ideal olarak algıladıkları evlenme yaşı ve buna ilişkin açıklamaları üzerinden ele alınmıştır. Katılımcıların evliliğe ilişkin tutumları ise görüşme sürecindeki genel söylemleri, evlenme ve çocuk sahibi olmaya ilişkin açıklamaları, cinsiyete göre farklılaşan açıklamaları ve kelime sıklı̆̆ı analizi üzerinden değerlendirilmiştir. Aynı zamanda elde edilen bulgular ilgili literatür ışı̆̆ında tartışılmıştır.

\section{1 İdeal Evlenme Yaşı ve Bu Düşüncede Etkili Olan Faktörler}

Araştırmada katılımcılara hangi yaşlarda evlenmek istedikleri sorulmuştur. Alınan yanıtlara göre öğrenciler çoğunlukla 24-29 yaş (n: 24) arasında evlenmeyi planladıklarını ifade etmiş, en sık tekrar edilen yaşlar ise 25-26 (n: 9) olmuştur. Bununla birlikte 30 ve üzeri yaşta (n: 2) evlenmeyi idealleştirdiklerini dile getirenler de olmuştur. Katılımcılar resmi istatistiklere ve araştırmalara (Akbaş vd., 2019; Al-Idah ve Farhadullah, 2017; Badger, 2005; Ghaili vd., 2012; Payne, 2017; TÜİK, 2020) paralel şekilde ideal evlilik yaşı olarak çoğunlukla 24-29 arasını ifade etmiştir. İstatistikler ve ideal evlenme yaşı algısı birlikte değerlendirildiğinde, üniversite gençlerinde evliliğin ertelenmesi eğiliminin olduğu görülmektedir. Bu durumun nedeninin gençlerin yetişkinlik rollerine girmekten kaçınması olduğu düşünülmektedir. Aynı zamanda cinselliğin evlilik hayatı dışında da kabul edilebilir hale gelmesi, evliliğin ertelenmesi eğilimi ile yakın ilişkili görülmektedir. Evlilik dışı birlikte yaşama ve evlilik öncesi cinselliğin yaygınlaştığına 
dair bulguları olan çalışmalar buna işaret etmektedir (Arnett ve Eisenberg, 2007; akt. Atak ve Çok, 2010; Evcili vd., 2013; Gökengin vd., 2003; Pınar, 2008; Scott vd., 2009).

Katılımcıların ideal evlilik yaşında etkili olan düşünceleri incelendiğinde sıklığına göre sırasıyla ekonomik bağımsızlığı kazandıktan sonra (f: 9), eğitimi tamamladıktan sonra (f: 8), özgürlüğün kısıtlanmasını istememe (f: 6), kariyer yaptıktan sonra (f: 3), olgunlaşmayı bekleme (f: 4) ve genç ebeveyn olmak isteme (f: 1) temalarının ortaya çıktığı görülmüştür. Evlenme yaşında etkili olan düşünce kategorisinde ortaya çıkan temalar Şekil 1'de gösterilmektedir.

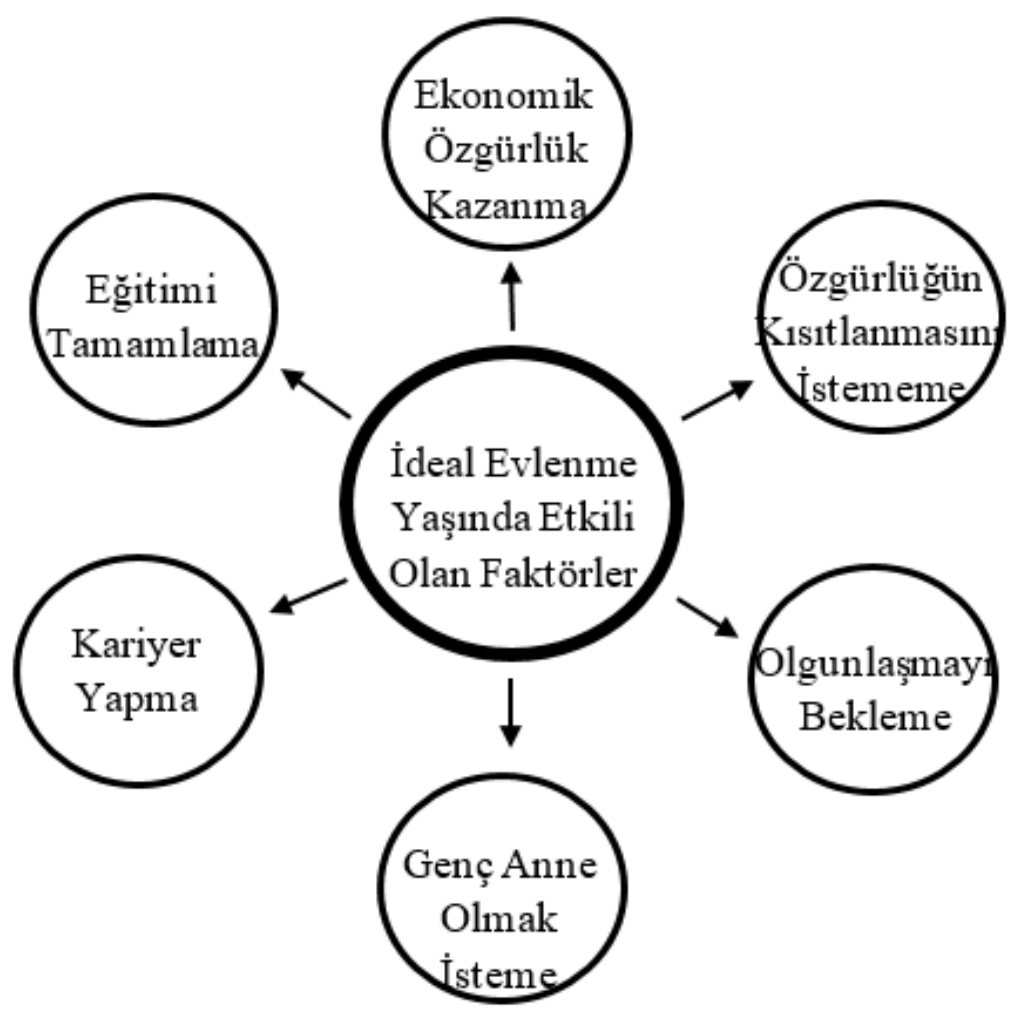

Şekil 1. İdeal Evlenme Yaşında Etkili Olan Faktörler

Ekonomik özgürlük kazanma, eğitimi tamamlama, olgunlaşmayı bekleme temaları gençler açısından yetişkinliğe, dolayısıyla evlilik hayatına geçişin belirleyicileri olarak görülmekteyken; özgürlüğün kısıtlanmasını istememe, evlilik öncesi kariyer yapmak isteme evliliğe ilişkin engelleyici, negatif bir bakışı yansıtmaktadır. Genç anne olmak isteme ise diğer yanıtlardan farklılaşarak daha erken evlilik-annelik tecrübesini olumlamaktadır. Üniversite öğrencileri evlilik sorumluluğunu üstlenmeden önce mesleki bir donamıma sahip olmayı ve bununla bağlantılı olarak ekonomik bağımsızlık kazanmayı, bu sayede daha ideal bir aile hayatı sürdürmeyi arzu etmektedir. 22 yaşında kadın öğrenci evlenme yaşında etkili olan ekonomik özgürlük kazanma düşüncesini “íkimizin de ayaklarımı üzerinde durması gerekiyor. En önemlisi ev almamız gerekiyor. Kira ödeyerek kendi geçimimizi çok zor sağlarız. Bunların hepsinin olabilmesi 
için de 28 yaş en uygunu. İki kişinin de maddi özgürlüğünü să̆laması gerekiyor.” (22-K) şeklinde ifade etmiştir. Aynı temada 22 yaşında erkek öğrenci “Ĕ̆ger istediŭim gibi iş de bulamazsam evlenmem de yani. İşi bulduktan sonra bile evlilik için beklerim. Çünkü belli bi birikimin olması gerekiyor. Öyle hadi iş buldum, hemen evleneyim kafasında değilim yani.” (25-E) demiştir.

Eğitimi tamamlama temasında 24 yaşında kadın öğrenci “Özellikle e ğitimime devam ettiğim için önceliğim okuldur. Bu okuma süreci de 23, 24 yaşlarını bulduğu için özellikle 25-26 evlilik için ideal bir yaştır." (12-K) demiştir. Eğitim seviyesi evliliğin ertelenmesi araştırmalarında sıklıkla ele alınan bir değişkendir. Bu çalışmalarda özellikle kadınların eğitim seviyesi arttıkça evlilik yaşının yükseldiği ifade edilmektedir (Rebick ve Takenaka, 2006; Sabbah-Karkaby ve Stier, 2017). Bu araştırmada da eğitimin devam etmesi evlilik yaşında etkili olan önemli faktörlerden biri olarak ortaya çıkmıştır.

“Bu yaşlarda insanın ev geçindirebilme olayını ve karı-kocalık ilişkisini daha net kavradığını düşünüyorum. Tabi bu benim için geçerli olan bir skala. Başka biri 19 yaşında bile bunları düşünmüşs olabilir ve evlilik için yeterince olgunlaştı̆̆ını düşünebilir. Bunu biraz kültürel yapıya bă̆llyorum. Yetiştirilme tarzı, daha sonradan edinilen veya oluşturulan kişilik vs. bu yapıya dahildir. Ama kendim için net olarak söyleyebilece ğim şudur ki; 25 yaşımda bile evlilik için hala olgunlaşmamış olduğumu düşünebilirim.” (14-K) ifadesi olgunlaşma temasını yansıtmaktadır. Bu aktarımlar gençlerin evliliğe ve yetişkin rollerine daha iyi hazırlanmak, daha ideal bir ilişki yürütmek için öncesinde bazı hedeflere ulaşmak istediklerini göstermektedir.

22 yaşında erkek öğrenci özgürlüğün kısıtlanmasını istememe temasında kendisini “Ben şu an kaldıramam mesela. Ben hayatımı yaşayacă̆ım, sonra evlenece ğim. Ĕ̆ger evlenirsem, evlenince yapamayacaklarımı yapıp sonra evlenirim. Akla gelen her şeyi... En basit dışarı çıkarken kimseye sormam. Ĕ̆lence hayatım olsun...” (4-E) şeklinde ifade etmiş, bir diğer öğrenci kariyer yapma temasında “Evliğimin belirlenmesi yaşımdan çok işimle alakalıdır. Kariyerim evliliğimin önündedir” (10-E) demiştir. Bu iki temada özellikle evliliğin bazı bireysel hedefler için engelleyici olarak düşünüldüğü görülmektedir.

Gençler evlenmeden önce eğitimini tamamlamayı, ekonomik bağımsızlık kazanmayı ve kariyer yapmayı hedeflemekte, özgürlüğün henüz kısıtlanmasını istememekte ve olgunlaşmak için zamana ihtiyaçları olduğunu düşünmektedir. Bu beklentiler evliliğe hazır oluşluk (Larson vd., 1988) kavramı ile açıklanabilmekte, gençlerin evliliğe hazırlanmalarını gerektiren bir dönem ihtiyacı hissettikleri görülmektedir. Kişinin evliliğin sorumluluklarını ve zorluklarını üstlenmeye hazır olduğunun öznel bir değerlendirmesi olan evliliğe hazır oluşluk kriterleri ile ilgili çalışmalar incelendiğinde benzer bulgulara ulaşan araştırmaların olduğu (Badger, 2005; Carroll vd., 2009; Ghalili vd., 2012), evliliğe hazırlık kriterlerinde ekonomik kayg1- 
ların ön plana çıktığg görülmektedir (Akbaş vd., 2019; Singerman, 2007). Ekonomik kaygılar, evlenme sürecine ilişkin yüksek maliyetler, işsizlik ve gelişmekte olan ülkelerde gençlerin beklentilerinin artması ekonomik hazırlık aşamasını zorlaştırıp, evliliğin ertelenmesinin nedenlerinden birisini oluşturmakta, evliliğe hazır oluşluk sürecini uzatmaktadır. Yürüttüğümüz araştırmada da benzer süreçlerin işlediği görülmüştür.

Gençler uzun bir tek yetişkinlik dönemi geçirip, çeşitli yaşam deneyimleri edinene kadar evliliğe hazır olmayacaklarına inanmaktadır (Badger, 2005). Bu algının beslendiği sosyal ve psikolojik faktörler, içinde bulunduğumuz dönemin öne çıkardığı değerler ile yakından ilişkilidir. Evliliğe hazırlıkta bireysel güven, bireysel özgürlük, bireysel hedefler, bireysel yeterlilik şeklinde modernizmin yansımalarının olduğu, "kendi ayakları üzerinde" durma (Baş ve Cengiz, 2018) argümanının kullanıldı̆̆ı görülmektedir. Bu noktada Badger'ın (2005) yaptı̆̆g yorum dikkate değerdir. Ona göre gençler evliliğe hazırlık sürecinde boşanmayı önlemeyi ve kaliteli bir evlilik hayatını amaçlamakta, aynı zamanda evliliğe hazırlandıkları kadar evlilik yolunda gitmezse boşanmaya da hazırlanmaktadırlar. Bu durum kişisel bağımsızlı̆̆ı vurgulayarak çiftler arası karşılıklı işbirliğini baltalamakta ve kişinin kendine yönelik bu aşırı ilgisi paradoksal olarak boşanma ihtimalini artırabilmektedir. Ghalili vd., (2012) de benzer şekilde gençlerin evlilikte başarısız olmaya karşı temkinli olduklarını ifade etmiştir. Bu temkinlilik durumu evliliğin daha ileriye ertelenmesiyle ilişkili görülmektedir.

\subsection{Evliliğe İlişkin Tutumlar}

\subsubsection{Evlilik ve Aileye İlişkin Genel Söylemler}

Bu kategoride görüşme yapılan öğrencilerin görüşme boyunca evlilik ve aileyi algılayışları, evlilik ve aileye ilişkin genel söylemleri incelenmiştir. Buna göre temel 9 tema belirlenmiştir (Şekil 2). Bu temalar sıklığına göre sırasıyla evliliği sorumlulukla ilişkilendirme (f: 42), evliliğin gençliği yaşamaya ve kişisel gelişime engel olarak görülmesi (f: 31), evliliğin ekonomik yönüne vurgu (f: 28), eşle ortak paylaşımlara vurgu (f: 18), evliliğin kutsallığını, önemini ve gerekliliğini vurgulama (f: 14), evlilikte sevgi, sayg1 ve sadakati vurgulama (f: 11), evlilikte erkeğe ekonomik yönden bağlı olmama vurgusu (f: 11), evliliği olgunlaşma ile ilişkilendirme (f: 5), evliliğe muhtaç olunmadığı vurgusudur (f: 4).

Öğrencilerin evlilik ve aileye ilişkin algılarında hem olumlu hem de olumsuz içeriğe sahip temaların olduğu görülmektedir. Evliliğin engel olarak görülmesi, erkeğe ekonomik bağımlılık algısı, evliliğe muhtaçlık vurguları olumsuz bakışı yansıtmaktadır. Aynı şekilde sorumlulukla ilişkilendirme temasında 


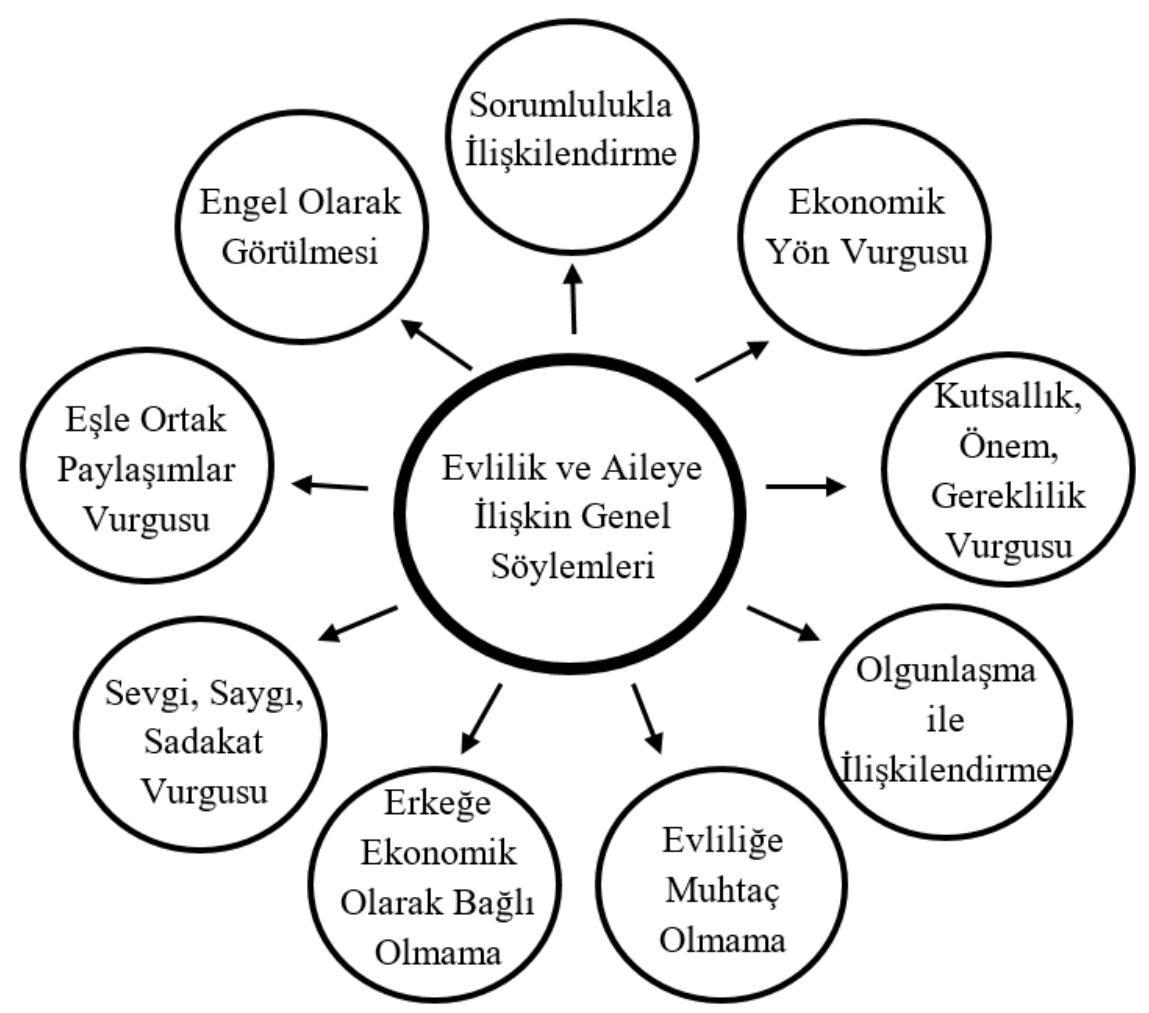

Şekil 2. Evlilik ve Aileye İlişkin Genel Söylemleri

evlilikte üstlenilmesi gereken sorumlulukların öğrencilerin zihninde negatif bir şekilde yer aldığı görülmüştür. Evlilikte üstlenilmesi gereken ekonomik sorumluluklar da evlilik algılarını olumsuzlaştırmakta, evliliğin gerektirdiği olgunluğa ulaşılamadığı düşünülmektedir. Bununla birlikte evlilik ve aile hayatının katkılarını ortaya koyan söylemler de mevcuttur. Eşle ortak paylaşımlar, evliliğgin kutsallığını ve önemini vurgulama, evlilikle sevgi-saygı ve sadakati ilişkilendirme evliliğe ilişkin olumlu tutumları yansıtmaktadır.

Öğrencilerin evlilik ve aileye yaklaşımlarında özellikle sorumluluk alma, evliliğin özgürlük ve bireysel hedefleri gerçekleştirme noktasında bir engel teşkil etmesi ve evliliğin ekonomik yönüne dair yaptıkları vurgular ön plana çıkmaktadır. 23 yaşındaki kadın öğrenci sorumlulukla ilişkilendirme temasında "Evliliğin zor yanlarından birisi de kişilere belli sorumluluklar yüklemesidir.” (17-K) demiştir. Aynı temada 22 yaşındaki erkek öğrenci kendisini “... hayatın sorumluluklarını üstlenmek zorunda kalıyorsun. Ben şuan kaldıramam mesela.” (4-E) şeklinde ifade etmiş, 21 yaşındaki bir diğer erkek öğrenci de benzer şekilde “Bir evin sorumluluğunu almaktan korkuyorum. Çünkü daha kendi sorumluluklarımı yerine getiremiyorum..." (5-E) demiştir. Öğrencilerin sorumlulukla ilişkilendirdikleri açıklamalar incelendiğinde, kendilerini sorumluluk alma yönünden eksik gördükleri ve bu durumun içerisinde bulundukları yaş evresinde evlilik yapma-aile kurma fikrinden uzaklaştırdığı görülmektedir. 
Evliğin engel olarak görülmesi temasında öğrenciler evliliği özgürlüğü, gençliği yaşamayı, bireysel hedefleri gerçekleştirmeyi ve kariyer yapmayı engelleyici olarak gördüklerini ifade etmişlerdir. Bu temada öne çıkan bazı ifadeler şu şekildedir: “Kendimle ilgili yapmak istediğim birçok planım var, bu planları hayata geçirmek istiyorum. Mesleğim dışında ilgili olduğum farklı bir alan var o alana yönelmek istiyorum. Ailemi mutlu etmek istiyorum, verdikleri emeklerin boşa çıkmadığını onlara göstermek istiyorum. Bundan dolayı evlilik benim için arka planlarda sayılabilir. ... aslında hep benden önce evlenenleri görünce veya duyunca içimden hep keşke hayallerine öncelik verselerdi, ailelerinin emeklerinin karşılığını keşke verselerdi diye geçiriyorum.” (20-K); “Evlilik özgürlü̆ü̈mü ister istemez kısıtlar. Rahatça gezip dolaşamam. Ben bunları seven bir insanım. Arkadaşlarımla istediğim kadar gezip ĕ̆lenemem.” (2-E)

Ekonomik yön vurgusu temasında da sorumluluk temasına benzer şekilde evin geçimini sağlamak için yeterli ekonomik kapasitede olmadıklarını vurgulamışlar, bu nedenle evlenme fikrinden uzak olduklarını ifade etmişlerdir. Bu temada 22 yaşında erkek öğrenci “... evlenen arkadaşlarım ciddi zor süreçlerden geçtiler. Özellikle ekonomik açıdan. Dolayısıyla olumlu bakmamaktayım.” (26-E) demiş, 22 yaşında kadın öğrenci de benzer şekilde "Evlenmek için para kazanıyor olmam lazım. Ve iş hayatında kabul görmek için günümüzde okulu bitirmek yanında birçok vasıf aranıyor.” (11-K) şeklinde kendini ifade etmiş̧tir. 24 yaşındaki erkek öğrenci ise “Gelir olduktan sonra o evlilik yürütülür.” (3-E) demiştir. Evlilikte olumsuz olarak algılanan ekonomik süreçlerden bir diğeri ise kadın öğrencilerin evlilik sürecinde eşlerine ekonomik olarak bağlı kalma kaygısıdır. “. . ekonomik olarak özgürleşip bir erke ğe bă̆lı kalmamalıyım.” (6-K) söylemi bunu yansitmaktadır.

Evliliği “muhtaç olma” vurgusu üzerinden olumsuz bağlamda ele alanlar da olmuştur. "Aslında evliliğe ihtiyaç duymuyorum. Evlenmeden de geçinebilirim. Ben farklı bakıyorum. Mesela sevgilim olmadan da olur. Birine muhtaçlık hissetmiyorum. Hayatımda biri olmadan da yapabilirim.” (5-E) ifadesi bunu yansıtmaktadır. Evliliğin belli bir olgunluk gerektirdiği de bulunan temalardandır: “Başka biri 19 yaşında bile bunları düşünmüşs olabilir ve evlilik için yeterince olgunlaştığını düşünebilir. Bunu biraz kültürel yapıya bağllyorum. Yetiştirilme tarzı, daha sonradan edinilen veya oluşturulan kişilik vs. bu yapıya dâhildir. Ama kendim için net olarak söyleyebilece ğim şudur ki; 25 yaşımda bile evlilik için hala olgunlaşmamış olduğumu düşünebilirim.” (14-K)

Öğrencilerin evlilik ve aile yaşantısını olumlayan ifadeleri de olmuştur. Eşle birlikte uyumlu vakit geçirmek, paylaşımlarda bulunmak bunlardan birisidir. “... Insan belli bir yaştan sonra hayat arkadaşı artyor. Ev işlerinden tut, beraber gezip e ğlenebileceğin birini istiyor, kafa dengi birini. Bu yüzden evliliğe ihtiyaç duyarım.” (4-E) ifadesi evlilikte ortak paylaşımlara dair vurguyu, dolayısıyla evliliğin sosyal destek 
işlevini yansıtmaktadır. Öğrenciler evliliğ̈in kutsallığını, önemini ve gerekliliğini de vurgulamıştır. Bir diğer erkek katılımcı evliliğin sosyal-duygusal fonksiyonlarına dayalı olarak evliliğin önemini vurgulamıştır: “... belirli bir yaştan sonra bence evlilik şart ve güzel bir şey. Her ne kadar eşin dostun olsa da akşam olduğunda yanında eşin ve ailen oluyor. Bizzat babamdan şahidim. (... Böyle bi olayda babamın en yakın dostum dediği adam sırtını dönüp gitmişti ama ailesi yine yanında şu anda. Bu çok basit bir örnek, daha ne olaylar olmuştur. O yüzden bence bu dünyada en büyük hazine gerçek bir aile.” (18-E). Bazı öğrenciler tarafından da evlilik sevgi, saygı, sadakat gibi olumlu değerlerle ele alınmışır: "Kısaca evlilik; karşıllıkl sevgi, saygı ve anlayıştır.” (18-E)

Pınar'ın (2008) yaptığı çalışmada öğrencilerin çoğu evliliği "sorumluluk alma" (\%94.2) ve "hayatı paylaşma" (\%98.5) şeklinde tanımlamışlardır. Bu araştırmada da katılımcıların evlilikle ilişkilendirdikleri olgular sorumluluk, engel, ekonomik yön, eşle ortak paylaşımlar, kutsallık-önem, sevgi-saygı-sadakat, erkeğe ekonomik yönden bağlı kalmama, olgunlaşma, muhtaç olmamadır. Bu olgularda evliliğe dair hem olumlu hem de olumsuz denebilecek, geleneksel ve alternatif yaklaşımların olduğu; aileyi işlevselliği ile ön plana çıkarma olduğu kadar engelleyici olduğu söylemlerinin de yer aldığı görülmektedir. Evlilik ve aile çalışmalarında da bu yaklaşımların izlerini görmek mümkündür. Bazı çalışmalar evliliğin bireysel ve toplumsal fonksiyonlarına odaklanırken; bazıları evlilikle çatışma, şiddet, istismar olgularını ilişkilendirmektedir. Gençlerin söylemlerinde bu bakış açılarının izlerinin olduğu, arada kalmış bir imaj sergiledikleri görülmektedir.

\subsubsection{Evlenme ve Çocuk Sahibi Olmaya Yakınlık}

Bu kategoride öğrencilerin evlilik kurumuna yakınlıkları, bakış açıları anlaşılmaya çalışılmıştır. Görüşme analizlerine göre "şimdi değil ama bir gün, yakın ve uzak" olmak üzere 3 tema ortaya çıkmıştır. Öğrencilerin çoğunluğunun (n: 21) evlenmeye ilişkin bakış açılarının "şimdi değil ama bir gün" temasına uygun olduğu görülmüştür. "Belirli bir yaşa kadar duymuyorum ama belirli bir yaştan sonra bence evlilik şart ve güzel bir şey." (18-E), "Şu an için ihtiyaç duymuyorum çünkü kendimi tam manasıyla tamamlamadı ̆̆ımı düşünüyorum ama ileride tabi ihtiyaç duyacă̆ım. Ben de isterim ailem olsun, sorumluluk alayım ve bu sorumlulukları zevkle yerine getireyim. Evlilik doğanın kanunudur." (20-K) ifadeleri evliliğe ilişkin "şimdi değil ama bir gün" yaklaşımına örnektir.

Bazı öğrenciler (n: 5) ise şu anda da evliğe hazır olduğunu belirmiştir. 22 yaşında, sosyoloji 3. Sınıf öğrencisi kadın "Yakın hissediyorum. Çünkü bir ev ve eş idare edebilecek beceride olduğumu düşünüyorum.” (11-K) demiştir. Benzer şekilde 24 yaşında yüksek lisans öğrencisi erkek katılımcının "Şu 
an yaş itibariyle hazır hissediyorum. Bir evliliğin sorumluluğunu alacă̆ımı düşünüyorum.” (3-E) ifadeleri evliliğe yakın olma temasına dairdir. 2 öğrenci ise evliliğe uzak olduğunu ifade etmiştir. 21 yaşındaki kadın katılımcının "Evliliğe ihtiyaç duymuyorum. Kendi her şeyimi karşılayabilecek bir durumdayken evlenip de birisiyle bir bütün olmak istemem. Yatağımı birisiyle paylaşmak istemem her gün aynı kişiyle yemek yemek, kahvaltı yapmak istemem. ... çok uzak hissediyorum. Evlilik benim alabilecĕgim bir sorumluluk de ğil. Çok kafama buyruk olduğum için ve istediğim her şeyi yapıp kimseye hesap vermediğim için uză̆ım.” (13-K) ifadesi evliliğe uzak, mesafeli olma temasına dairdir. Katılımcı kişilik özellikleri nedeniyle evlilik ilişkisine uygun olmadı̆̆ını vurgulamıştır.

Katılımcıların çoğunluğunun evliliği erteleme eğilimlerinin olmasına rağmen, evliliğe yönelik olumlu bir tutumlarının olduğu görülmektedir. Türkiye’de ve dünyada üniversite öğrencileri üzerinde yürütülen evlilik ve aile algısı ile ilgili araştırmalarda da üniversite öğrencilerinin, evlilik ve aile yaşamına karşı duyarlı oldukları ve evlilik düşüncesine olumlu baktıkları bulgulanmıştır (Akbaş vd., 2019; Baş ve Cengiz, 2018; Bener ve Günay, 2013; Pınar, 2008; Scott vd., 2009). Gençler için evlilik hala önemli bir kurumdur, fakat onu gelecekte planlama eğilimi vardır. Gençler uzun bir bekarlık evresinden sonra evlenmeyi ummakta, bu süreçte ekonomik bağımsızlık kazanmayı; seyahat etmek, eğlence hayatı yaşamak gibi evliyken gerçekleştirmenin zor olduğunu düşündüğü şeyleri hayata geçirmeyi planlamaktadır. Gençler evliliği hayatlarında olması gereken bir olgu olarak görmekte, fakat kapasitelerinin henüz evlenmek için yeterli olmadığına inanmakta, evliliğe hazır hale gelmek için uzun bir bekarlık dönemi geçirerek, çeşitli yaşam deneyimleri edinmeleri gerektiğini düşünmektedir. Özellikle evliliği sorumlulukla ilişkilendirerek, henüz evlilik sorumluluğunu alabilecek kapasitede olmadıklarını vurgulamaktadırlar. Yapılan bir araştırmada öğrencilerin \%40’ının evlilikten korktuğu bulunmuştur (Akbaş vd., 2019). Bu durum evliliklerin olumlu işlevlerinden ziyade; şiddet, istismar, boşanma gibi sorunlarla daha sık ilişkilendirilmesinin bir yansıması olarak değerlendirilebilir. Bu algı gençlerin yetişkinlik hayatına adım atmalarını güçleştirmekte, bu dönemin özel olarak incelenmesini gerektirmektedir. Gelişime özgü dönemlerin kültürel faktörlerden doğrudan etkilendiği göz önüne alındığında, günümüzde evlilik ve aile kurmaya yönelik kriterlerin, evlilik beklentilerinin ne kadarının gelişimsel ne kadarının psikolojik, sosyolojik, kültürel bariyerlerle ilişkili olduğunun tartışılması gerekmektedir. Evlilik ve aileye ilişkin sorunları (ekonomik, ilişkisel, duygusal, sorunlar vb.) merkeze alan, bireysel hedefleri ön plana çıkaran yaklaşımların gençlerin evlilik tutumlarını etkilediği düşünülmektedir. Çeşitli araştırmacıların (Al-Idah ve Farhadullah, 2017; Badger, 2005: 6; Ghalili vd., 2012, s. 1080; Tezcan ve Coşkun, 2004, s. 29) vurguladığ gibi gençlerin evlenmeye hazır olma sürecinde istenmeyen bazı sonuçlara neden olabilecek önlemler aldıkları görülmektedir.

Katılımcıların çocuk sahibi olmaya dair algılarını anlamak için "Evlenince çocuk sahibi olmak ister mi- 
sin?” sorusu yöneltilmiştir. Katılımcıların çoğunluğu (n: 25) çocuk sahibi olmak istediğini dile getirmiştir. “Kesinlikle çocuk sahibi olmak istiyorum. 28-29 yaşımda çocuğumun olmasını isterim. Kendi canından bi çocuğun olması ayrı bir mutluluk benim için. Onunla beraber vakit geçirmek, gezmek, eğlenmek istiyorum. En büyük hayallerimden bir tanesi 1 erkek 1 kız çocuğum olsun isterim.” (25-E), “Tabi ki isterim. Bence her kadın annelik duygusunu tatmak ister. Çocuk evin neşesidir. Yaş konusunda belirli bir şey söyleyemem. Bazen farklı nedenlerden dolayı çocuk sahibi olamayabiliriz.” (17-K) ifadeleri çocuk sahibi olmaya ilişkin olumlu bakışı göstermektedir. 1 katılımcı ise ekonomik yükünden dolayı çocuk sahibi olmak istemediğini belirtmiş “Çocuk istemiyorum. Kendim çok masraflı bir çocuktum. .. y yani yeni doğduğunda bez masrafi hastane masrafi, okul zamanı kurs masrafi, servis masrafi, ergenliğinde terbiyesizliklerine susmak gerek, üniversitede ev masrafları vs çok fazla masraf oluyor. Bir çocuk yetiştiresiye kadar ben bir sürü ülke gezip, kendimi iyi yetiştirmeyi tercih ediyorum.” (22-K) demiştir. Öğrencilerin evlenme ve çocuk sahibi olma konusunda çoğunlukla ailenin geleneksel rollerine yakın oldukları, büyük çoğunluğunun çocuk sahibi olma fikrini idealleştirdiği görülmektedir. Bu bulgu evliliğe ilişkin algılarıyla birlikte değerlendirildiğinde gençlerin hem geleneksel hem de geleneksel olmayan eğilimleri barındıran bir geçiş döneminde oldukları yorumu yapılabilir. Türk ailesinde geleneksel ve modern unsurların bir arada bulunduğu, geleneksel aile yapısından modern yapıya doğru bir geçiş yaşandığı sıklıkla yapılan bir değerlendirmedir (Aluş ve Selçukkaya, 2015; İmamoğlu, 1993; İşmen-Gazioğlu, 2006; Okman-Fişek ve Scherler, 1996).

\subsubsection{Evlilik ve Aileye İlişkin Söylemlerde Cinsiyet Değişkenine İlişkin Farklılıklar}

Kadın ve erkek öğrencilerin evlilik tutumlarının farklılaşabileceğinden hareketle, katılımcıların tüm görüşme sürecindeki ifadeleri değerlendirilmiş ve bazı temalarda kadın ve erkek öğrenciler arasında farklılıklar olduğu görülmüştür. Erkek öğrenciler evlilik ve aileye dair ekonomik açıklamaları (E: 35/K: 19) ve sorumluluk vurgusunu (E: 36/K: 22) kadın öğrencilerden daha fazla yapmışlardır. Evliliğin engel olarak görülmesi temasında ise kadın öğrenciler erkek öğrencilerden daha fazla içerik sağlamışladır (K: 21/E: 10). Kadınların "engel olarak görme", erkeklerin ise "ekonomik faktörler" ve "sorumluluk"

ile ilişkilendirme eğilimlerinin daha yüksek olduğu görülmektedir. Buna göre kadınların daha bireysel, erkeklerin ise ilişkisel faktörleri öncelediği, aynı zamanda evlilik yaşantısında kadının erkeğe oranla kendisini daha fazla sınırlanmış hissedeceğini düşündüğü söylenebilir. Bu bulgu Türk toplumunda kadınların modernleşme sürecinin daha hızlı olduğuna (İmamoğlu, 1993) ilişkin yorumları destekleyen bir bulgu olarak değerlendirilebilir. 


\subsubsection{Kelime Sıklığı Analizi}

Görüşme dökümleri üzerinde kelime sıklığı analizi gerçekleştirilmiştir. Bunun için görüşmecinin soru sorduğu, konuştuğu yerlere dair dökümler çıkartılıp, sadece görüşülen kişilerin ifadeleri bırakılmıştır. Bu analize göre katılımcıların en sık kullandıkları 10 kelime evlilik (f: 125), daha (f: 112), yaş (f: 94), olarak (f: 87), çünkü (f: 84), erken (f: 74), ben (f: 73), isterim (f: 61), çocuk (f: 58), geç (f: 56) kelimeleridir. Sık kullanılan kelimeler araştırma bağlamında beklenen kelimelerdir. Buna dayalı olarak görüşmelerin araştırma amacına uygun gerçekleştirildiği görülmektedir. Bununla birlikte sık kullanılan kelimelerden de içerik analizinde ortaya çıkan temalara paralel şekilde evliliği kendi yaşlarında henüz erken gördüklerine dair kelimelerin öne çıktığı anlaşılmaktadır. Buna dayalı olarak öğrencilerin içerisinde bulundukları gelişim döneminde evlenmeyi erken gördükleri söylenebilir. Sık kullanılan kelimelerin görselleştirilmiş hali Şekil 3'te görülmektedir.

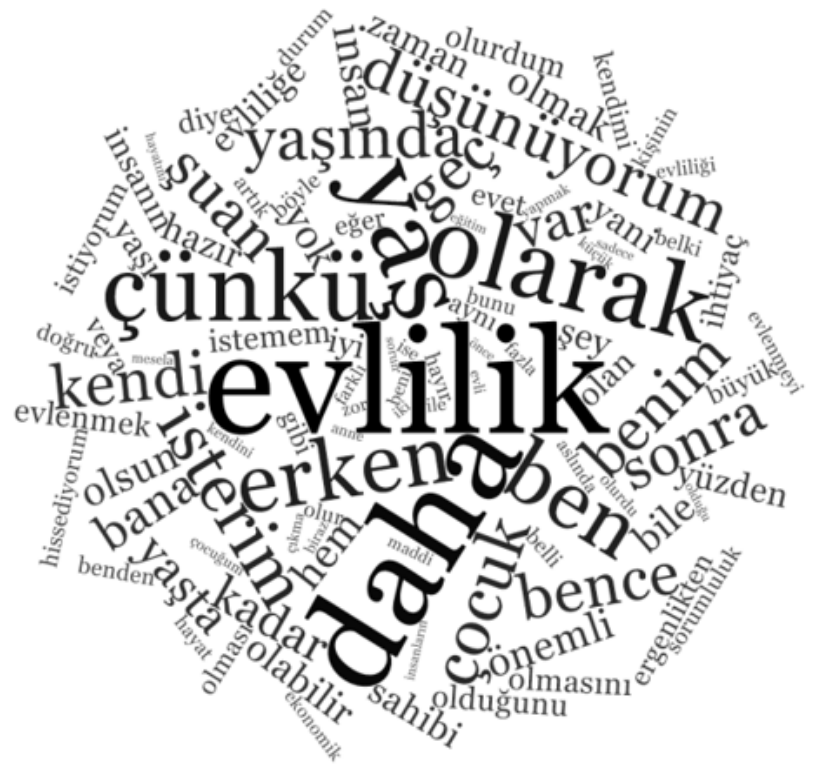

Şekil 3. Kelime Bulutu Uygulamasıyla Kelime Sıklığı Analizi

\section{Sonuç ve Öneriler}

Aile yaşamı geçmişten günümüze değişmekte, evliliğe ilişkin beklentiler kuşaklar arasında oldukça farklılaşmaktadır. Bu araştırmada evlilik ve aile olgusu gençlerin bakışı üzerinden değerlendirilmiş, bekâr üniversite öğrencilerinin evlilik ve aile hayatına ilişkin algıları nitel araştırma yöntemlerinden fenomenolojik yaklaşımla, yarı yapılandırılmış görüşmeler gerçekleştirilerek anlaşılmaya çalışılmıştır. 
Araştırmanın nitel araştırma olması nedeniyle, bulguların genellenmesi mümkün olmamakla birlikte, bu konuda önemli fikirler vermektedir. Yapılan bu araştırmada ülkemiz gençliğin büyük bir bölümünü oluşturan üniversite gençliğinden küçük bir kesit alınmış ve buna göre gençlerin dünyasında evlilik ve aile kurumunun hala önemli bir yere sahip olduğu görülmüştür. Bununla birlikte gençlerde evliliğin ertelenmesine dair bir eğilimin olduğu, evlilik kurumuna dair geleneksel olduğu kadar gelenekselden uzaklaşan eğilimlerin de olduğu "arada” bir tablo ortaya çıkmaktadır. Gençler günün birinde evlenmek istemekte; ancak içinde bulundukları gelişim döneminde evliliğe henüz hazır olmadıklarını, evliliği yürütebilecek beceri ve yetkinliklere sahip olmadıklarını, yetişkinlik hayatına geçiş için ara döneme ihtiyaç duyduklarını yansıtmaktadırlar. Evliliği erteleme eğilimi; eğitimi tamamlama, kariyer yapma, belli bir olgunluğa ulaşma, ekonomik bağımsızlığını elde etme gibi şartların yerine getirilmesi sayesinde daha ideal bir evlilik yapmak niyetiyle gerekçelendirilmektedir. Bu temkinlilik hem evliliğin ertelenmesi düşüncesine yol açmakta, hem de kişinin kendisine yönelik bu yoğun ilgisi evlilik uyumunu olumsuz etkileme potansiyeline sahip görünmektedir.

Bu bulgulara dayalı olarak gençlerin evlilik ve aile hayatı becerilerini geliştirme yönünde çalışmaların yapılması önerilebilir. Aynı zamanda ülkemiz için evliliğin ertelenmesi eğiliminin toplumsal sorunlarla ilişkisinin tartışılması gerekmektedir. Bu bağlamda akademisyenlerin özellikle gençlerin evlilik ve aile hayatına yönelik tutumlarına, bu tutumlara etkide bulunan faktörlere ve bu tutumların olası sonuçlarına daha fazla ilgi göstermesi önerilmektedir.

\section{Kaynaklar}

Akbaş, M., Sürücü, Ş. G., Köroğlu, C. O. ve Öztürk, M. (2019). Üniversite öğrencilerinin evlilik tutumlarını etkileyen faktörler. Cukurova Medical Journal, 44 (1), 93-100.

Al-Idah, J. E., Farhadullah, Fazl E umar. (2017). Delayed Marriages from Islamic point of view in Pakistani Society. Al-Idah I Shaykh Zayed Islamic Centre, University of Peshawar, 34 (1), 85-97.

Aluş, Y. ve Selçukkaya, S. (2015). Türk ailesinde mutluluk algısı ve değerleri. Sosyal ve Kültürel Araştırmalar Dergisi, 1(2), 151-175.

Arnett, J.J. (2000). Emerging adulthood: A theory of development from the late teens through the twenties. Am Psychologist, 55, 469-480.

Atak, H. ve Çok, F. (2010). İnsan yaşamında yeni bir dönem: Beliren yetişkinlik. Çocuk ve Gençlik Ruh Să̆lı̆̆g Dergisi, 17(1), 39-50. 
Atak, H., Tatlı, C., Çokamay, G., Büyükpabuşcu, H. ve Çok, F. (2016). Yetişkinliğe geçiş: Türkiye'de demografik ölçütler bağlamında kuramsal bir gözden geçirme. Psikiyatride Güncel Yaklaşımlar, 8 (3), 204-227.

Aziz, A. (2014). Sosyal bilimlerde araştırma yöntem ve teknikleri, Ankara: Nobel Yayınları.

Badger, S. (2005). Ready or not? Perceptions of marriage readiness among emerging adults (Unpublished Doctoral Thesis). Brigham Young University.

Baş, E. ve Cengiz, E. (2018). Üniversite öğrencilerinin evlilik ve aileyi anlamlandırma biçimleri: Karadeniz Teknik Üniversitesi örneği. İmgelem, 2 (2), 5-27.

Başar, U. (2020). Iran'da değişen evlilik ilişkileri. Ankara: İRAM Yayınları.

Bazeley, P. ve Jackson, K. (2015). NVIVO ile nitel veri analizi. A. Bakla, S. Beşir Demir (Çev.). Ankara: Anı Yayıncilık.

Benatar, D. (2018). Keşke hiç olmasaydık: Var olmanın kötülüğ̈̈̈. C. Özge Özmen (Çev.) İstanbul: DoğuBatı Yayınları.

Bener, Ö. ve Günay, G. (2012). Gençlerin evlilik ve aile yaşamına ilişkin tutumları. Karabük Üniversitesi Sosyal Bilimler Enstitüsü Dergisi, 2 (1), 1-27.

Carroll, J. S., Badger, S.,Willoughby, B. J., Nelson, L. J., Madson, S. D. ve Barry, C. M. (2009). Ready or not criteria for marriage readiness among emerging adults. Journal of Adolescent Research, 24 (3), 349-375.

Erdoğan, E. (2017). Türkiye'de gençlerin iyi olma hali araştırmast, HABİTAT: https://habitatdernegi.org/wp-content/uploads/turkiye-de-genclerin-iyi-olma-hali-raporu.pdf (Erişim Tarihi: 08.06.2020).

Eurostat (2018). Mean age at first marriage by sex. https://ec.europa.eu/eurostat/web/products-datasets/Itps00014 (Erişim Tarihi: 10.06.2020).

Evcili, F., Cesur, B., Altun, A., Güçtaş, Z. ve Sümer, H. (2013). Evlilik öncesi cinsel deneyim: Ebelik bölümü öğrencilerinin görüş ve tutumları. Gümüşhane Üniversitesi Sağllk Bilimleri Dergisi, 2 (4),486-498. 
Ghalili, Z., Etemadi, O., Ahmad Ahmadi, S., Fatehizadeh, M. ve Abedi, M. R. (2012). Marriage readiness criteria among young adults of Isfahan: A qualitative study. Interdisciplinary Journal Of Contemporary Research In Business, 4 (4),1076-1083.

Giddens, A. (2000). Sosyoloji. Ankara: Ayraç Yayınevi.

Gökengin, D., Yamazhan, T., Özkaya, D. ve Aytuğg, Ş. (2003). Sexual knowledge, attitudes and risk behaviors of students in Turkey. J Sch Health, 73.

Groenemeyer, A. (2007). Social problems, concept and perspectives. G. Ritzer (Ed.), in The Blackwell Encyclopedia off Sociology. Australia: Blackwell Publishing, 4503-4509.

İmamoğlu, O. (1993). Değişen dünyada değişen aile içi roller. Kadın Araştırmaları Dergisi, 1, 58-68.

İşmen-Gazioğlu, E. (2006). Genç yetişkinlerin evlilik ve aile hayatına ilişkin görüşlerinin değerlendirilmesi. Marmara Üniversitesi Atatürk Ĕ̆gitim Fakültesi Ĕ̆itim Bilimleri Dergisi, 23(23), 107-123.

Jones, G. W.(2010). Changing in marriage patterns in Asia. Singapore: Asia Research Institute, Working Paper No: 131.

Jones, G.W. ve Yeung, W. J. (2014). Marriage in Asia. Journal of Family Issues, 35 (12).

Kabakçı-Yurdakul, I. (2016). Nitel Veri Analizinde Adım Adım NVivo Kullanımı. Ankara: Anı Yayıncılık. Komisyon (1998). Türk gençliği 98: Suskun kitle büyüteç altında. İstanbul: Konrad Adenauer Vakfi Yayınlar1.

KONDA (2020). 10 yılda gençlerde ne değişti?. https://interaktif.konda.com.tr/tr/Gencler2018/\#firstPage, (Erişim Tarihi:08.06.2020).

Larson, J. H., Benson, M. J., Wilson, S. M. ve Medora, N. (1998). Family of origin influences on marital attitudes and readiness for marriage in late adolescents. Journal of Family Issues. 19 (6), 750-768.

Marshall, G. (1999). Sosyoloji sözlü̆̆̈̈. Ankara: Bilim ve Sanat Yayınları.

Nedelmann, B. (2001). The continuing relevance of Georg Simmel: Staking out anewthe field of sociology. Ritzer, G. ve B. Smart (Ed.), in Handbook of Social Theory. London: Sage.

Okman-Fişek, G. ve Scherler, H. R. (1996). Toplumsal değişim ve eşler: Cinsiyet senaryolarının sınırlarını genişletme amaçlı bir terapi yaklaşımı. Türk Psikoloji Dergisi, 11 (36), 1-11. 
Payne, K. K. (2017). Median age at first marriage. National Center For Family \&Marriage Research.

Pınar, D. (2008). Üniversite son sınıf öğrencilerinin evliliğe bakış açısı. Sosyal Politika Çalışmaları Dergisi, 14 (14), 49-60.

Rebick M. ve Takeneka, A. (2006). The changing Japanese family. Routledge: London and New York.

Sabbah-Karkaby, M. ve Stier, H. (2017). Links between education and age at marriage among Palestinian women in Israel: Changes over time. Studies in Family Planning, 48 (1), 23-38.

Özgür, S. (2019). Aile kurumu ve ailenin tanımı. M. Aydın (Ed.), Sistematik aile sosyolojisi içinde. Konya: Çizgi Kitapevi.

Sayın, Ö. (2020). Aile sosyolojisi. Ankara: Doğubatı Yayınları.

Scott M. E., Schelar E. Manlove, J. ve Cui, C. (2009). Young adults attitudes about relationships and marriage: Times may have changed, but expectations remain high. Child Trends Research Brief.

Seggie, F. N. ve Bayyurt, Y. (2015). Nitel araştırma yöntem, teknik, analiz ve yaklaşımları. Ankara: Anı Yayıncilik.

Singerman, D. (2007). The economic imperatives of marriage: Emerging practices and identities among youth in the Middle East. Washington: Wolfensohn Center for Development.

Sunar, L. (2018). Değisşim sosyolojisi: Kavramlar, kuramlar ve yaklaşımlar. Ankara: Nobel Yayınları.

Şimal, N. (2019). Üniversite Son Sinıf Öğrencilerinin Çocuk Sahibi Olma İsteğini Etkileyen Faktörler (Yayınlanmamış Yüksek Lisans Tezi). Eskişehir Osmangazi Üniversitesi Sağlık Bilimleri Enstitüsü.

Tezcan, S. ve Coşkun, Y. (2016). Türkiye'de 20. yüzyılın son çeyreğinde kadınlarda ilk evlenme yaş1 değişimi ve günümüz evlilik özellikleri. Nüfusbilim Dergisi, 26 (1), 15-34.

The Economist (2011). Asian demography: The flight from marriage. https://www.economist.com/briefing/2011/08/20/the-flight-from-marriage (Erişim Tarihi: 10.06.2020).

Türkiye İstatistik Kurumu (2019). Dünya Nüfus Günlüğ̈̈, 2019-Haber Bülteni. https://tuikweb.tuik.gov.tr/HbPrint.do?id=30710 (Erişim Tarihi: 29.05.2020). 
Türkiye İstatistik Kurumu (2020). Evlenme ve boşanma istatistikleri. 2019-Haber Bülteni. http://www.tuik.gov.tr/PreHaberBultenleri.do?id=33708 (Erişim Tarihi: 29.05.2020).

Uğur, Z. B. (2018). Çocuk sahibi olmak insanları mutlu ediyor mu? Türkiye'den bulgular. Nüfus Bilim Dergisi, 40, 83-105.

Yıldırım, A. ve Şimsek, H. (2006). Sosyal bilimlerde nitel araştırma yöntemleri. Ankara: Seçkin Yayıncılık.

Yıldırım, E. (2011). Toplumsal değişme sürecinde aile. K. Canatan ve E. Yıldırım (Ed.), Aile sosyolojisi içinde. İstanbul: Açılım Kitap.

Yu-lan, F. (2019). Çin felsefesi tarihi. F. Aydın (Çev.). İstanbul: Bilgi Üniversitesi Yayınları.

\section{Makale Bilgi Formu}

Yazar(lar)ın Katkıları: Makaleye tüm yazarlar eşit katkı sağlamıştır.

Çıkar Çatışması Bildirimi: Yazarlar tarafından potansiyel çıkar çatışması bildirilmemiştir.

Destek/Destekleyen Kuruluşlar: Bu araştırma için herhangi bir kamu kuruluşundan, özel veya kâr amacı gütmeyen sektörlerden hibe alınmamıştır.

Etik Onay ve Katılımcı Rızası: Çalışma etik ilkelere uygun ve katılımcı onayı alınarak gerçekleştirilmiştir.

Bu çalışmanın yazım sürecinde bilimsel, etik ve alıntı kurallarına uyulmuş; toplanan veriler üzerinde herhangi bir tahrifat yapılmamış, karşılaşılacak tüm etik ihlallerde "Universal Jounal of History and Culture" hiçbir sorumluluğu olmayıp, tüm sorumluluk yazarlara aittir. 